\title{
The Effect of Pressure to Financial Statement Fraud (Study of Manufacturing Companies Listed on the Indonesian Stock Exchange)
}

\author{
Ni Wayan Yuniasih ${ }^{1}$, Ni Ketut Muliati ${ }^{2}$, Cokorda Gde Bayu Putra ${ }^{3}$, Ida Ayu Made Sasmita Dewi ${ }^{4}$ \\ \{yuniasihwayan@gmail.com ${ }^{1}$, ketutmuli@yahoo.com ${ }^{2}$, cokdebayu88@gmail.com ${ }^{3}$, \\ dayusasmitaunhi@gmail.com $\left.{ }^{4}\right\}$
}

Faculty of Economics, Business and Tourism, Hindu Indonesia University, Indonesia ${ }^{1,2,3,4}$

\begin{abstract}
This study aims to examine the effect of pressure factors on the occurrence of financial statement fraud. The pressure aspect is seen in three forms, namely financial stability, financial target, and external pressure. The study was carried out in 2015-2017 at 69 production companies listed on the Indonesia Stock Exchange. Hypothesis testing is performed using multiple linear regression procedures. The study results showed that financial stability and external pressure had an effect on fraud's financial statements, whereas the financial target had no effect on fraud in financial statements. The results of this study indicate that pressure from external companies is more likely to trigger fraud than internal pressure. This may be influenced by the company's interests in keeping investors at the value of the company.

Keywords: external pressure, financial stability, financial target, financial statement fraud
\end{abstract}

\section{Introduction}

The Financial Statements function to provide stakeholders with information on company finances for a single period. Financial statements users are shareholders, other investors and creditors according to the FASB. The company's purpose in issuing financial statements is in fact to show the company's best state. Yet this motivation can lead to the company's fraudulent financial reporting. Financial statements fraud makes the information in the financial statements irrelevant and causes material mistakes that can mislead users of the financial statements. Almost all cases of fraud that occur involve unethical hiding experiments (Dalnial, Kamaluddin, Sanusi, \& Khairuddin, 2014).

For example, in Indonesia cases can be raised that occurred in PT. Kimia Farma. Based on indications from the BUMN Ministry and its review, it was found that there were misstatements in the financial statements resulting in overestablishment of net income for the year ended 31 December 2001 of $\mathrm{Rp} 32.7$ billion, which represents $2.3 \%$ of sales and $24.7 \%$ of net revenues. Fraud is a deliberate act to cheat, deceive or dishonest ways to take or eliminate money, property, legitimate rights owned by another person either because of an action or fatal impact of the action itself. Fraud can be done by individuals, but it can also be done by a group of people within the organization who work together in the practice of fraud (Skousen, Smith, \& Wright, 2009)

In general, fraud always occurs when prevention and detection are not previous. Therefore, there are several ways to detect fraud such as fraud triangles and fraud diamond. Cressey (1953 Suggested three conditions in order to identify factors affecting fraudulent actions, namely pressure, opportunity and rationalization, known as triangular fraud. Additionally, (Wolfe \& Hermanson, 2004) add three conditions that have been found by Cressey (1953) in (Skousen \& Twedt, 2009) with capability, so that the four conditions are called fraud diamond.

Someone in a state of not being depressed would not commit fraud even though there was an opportunity (Nursani \& Irianto, 2016). The most frequent pressure is the pressure that comes from the financial actors who commit fraud, although there are still other pressure factors such as pressure from outside parties. Research conducted by (Annisya \& Asmaranti, 2016) results found that financial stability had a significant positive effect on fraud in the financial statements. Research conducted by (Quraini \& Rimawati, 2019) the external pressure was found to have a significant positive effect in detecting fraud in the financial statements. Putri, et al. (2017) it has also been found that financial targets and ineffective monitoring have a positive effect on the fraud in financial statements.

Research on fraud is interesting as the development of fraud cases is increasing. The results of various previous studies were motivated to do research again. Based on this background, this study aims 
to test the pressure factor for manufacturing company's financial statements fraud listed on the Indonesia Stock Exchange in 2015-2017.

\section{Literature Review and Research Hypotheses}

Jensen \& Meckling (1976) stated that the relationship between the agency arises as a result of a contract between the principal and the agent by delegating some authority to the agent to take decisions. In accordance with the agreement, it can be assumed that some decisions will give authority to the agent. Company managers acting as agents are responsible for increasing the owners '(principals') profits but managers are also interested in maximizing their welfare. This difference of interest can result in a conflict of interest between the agent and the principal that triggers the cost of the agency. This conflict encourages fraud so as to maximize one party's interests.

Clinard \& Cressey (1954) Triangle fraud introduced which can be used to detect the cause of the fraud. The three factors that cause fraud are: pressure, opportunity and streamlining. Pressure leads to somebody committing fraud. Pressure most often stems from the financial pressures. This need is often considered a need that can not be shared with others to solve it jointly, so that it has to be resolved secretly and ultimately lead to fraud.

Pressure gives someone the motivation to commit fraud because of financial burdens (Murtanto \& Umar, 2016). Pressure can also be said to be the desire or intuition of someone urged to commit a criminal offence.(Skousen et al., 2009) There are a number of pressure conditions that cause a person to commit fraud, namely: financial stability, external pressure, personal financial need and financial objectives.

According to SAS No. 99 (Skousen et al., 2009) explained that managers face pressure to commit fraud and manipulation of financial statements when economic, industrial, and other situations threaten financial stability and profitability of their companies. Loebbecke and Bell in (Skousen et al., 2009) It indicated that companies were growing below the industry average, enabling management to manipulate financial statements to improve the prospects for companies. Research conducted by (Skousen et al., 2009) proves the possibility of fraud is influenced by the growth of assets which are positive fast. (Sihombing \& Rahardjo, 2014), financial stability proxy by changes in total assets (ACHANGE) has been shown to have an influence on fraud in financial statements. On the basis of the description the proposed hypothesis is:

$\mathrm{H}_{1}$ : Financial stability has a positive effect on financial statement fraud.

Managers are striving to improve their performance to achieve various company goals, one of which being financial goals (Skousen et al., 2009) state Return on Total Assets (ROA) is an operating performance measure widely used to demonstrate how assets were used efficiently. This is supported through (Kasmir, 2019) who says ROA is a ratio showing a return (return) on the amount the company has used. Hence, ROA is used as a proxy for the variable financial targets.

The study of (Skousen et al., 2009) The Return on Assets (ROA) was found to have no effect on fraudulent financial statements. This result is supported (Sihombing \& Rahardjo, 2014) study which states that ROA proxies of financial target variables have no effect on fraud in financial statements. Often, the profit achieved in the previous year is used as the basis for the following year's profit targets. High ROA illustrates how effective the firm's overall operation has beenIt is only that by increasing its performance by targeting higher ROA, management enables financial statements to be cheated in the form of earnings management. Based on the description, the hypothesis proposed in this study is: H2: Financial Targets have a positive effect on financial statement fraud.

Skousen et al., (2009) the source of external pressure was said to be one of the ability of the companies to pay debts or meet debt requirements. Additionally, managers can also be under pressure to obtain additional debt or capital. This was also revealed by (Aprillia, Cicilia, \& Pertiwi Sergius, 2015) Who said that external pressure is the ability to meet the exchange requirements for the recording, payment of debts or fulfillment of the debt of widely recognized agreements originating from outside parties. External pressure is calculated using the leverage ratio, which is the ratio of total debt divided by total assets (the ratio of debt to assets). When a firm has a high leverage ratio, it has a large debt (Kasmir, 2019). The company's management will feel pressured by the rising debt, as the credit risk will also be high allowing fraud to occur.

Research by the (Skousen et al., 2009) Prove that external pressure has no bearing on fraud. This was backed by (Aprillia et al., 2015) External pressure proxied by the use of a leverage ratio proxy that 
did not affect the fraud in the financial statements. Whilst research is carried out by (Sihombing \& Rahardjo, 2014) state that external pressure has an influence on the detection of fraudulent accounts Quraini \& Rimawati (2019) showed that the influence of external pressure expected fraudulent financial report. The hypothesis we formulated for the above explanation is as follows:

H3: External Pressure affects the financial statement of fraud.

\section{Research Method}

To support the data studied, a variable analysis is needed to be used in conducting research in accordance with existing problems. Before conducting research, each variable needs to be defined.

\subsection{Financial Stability $\left(\mathbf{X}_{1}\right)$}

Skousen et al., (2009) prove that the higher the ratio of changes in a company's total assets, the greater the possibility of a company's fraudulent financial statements, the ratio of changes in total assets is used as a proxy for financial stability (financial stability). In this study, financial stability is proxy by the ratio of change in total assets (ACHANGE), which is calculated by the formula:

$$
\text { ACHANGE }=\frac{\left(\text { Total Aset }_{t}-\text { Total Aset }_{t-1}\right)}{\text { Total Aset }_{t-1}}
$$

\subsection{Financial Target $\left(\mathrm{X}_{2}\right)$}

Return on assets in this study has been used as a proxy for financial targets. Return on Assets (ROA) is part of the profitability ratios for the analysis of financial statements or the measurement of company performance (Skousen et al., 2009). ROA (Kasmir, 2019) can be calculated using the following formula:

$$
\text { ROA }=\frac{\text { Earning After Interest and Tax }}{\text { Total Assets }}
$$

\subsection{External Pressure $\left(\mathbf{X}_{3}\right)$}

External Pressure is excessive Management Pressure to meet third party requirements or expectations. The Leverage Ratio (LEV) is proxy for external pressure in this study. The leverage ratio is calculated by the formula Debt to Assets Ratio (Kasmir, 2019), namely:

$$
\text { Debt to Assets Ratio = Total Debt }
$$

$$
\text { Total Assets }
$$

\subsection{Financial Statement Fraud (Y)}

The dependent variable used in this study is fraud with the financial statements. This study detected fraudulent accounts (fraud in financial statements) using the fraud score model as determined by (Dechow, Hutton, Kim, \& Sloan, 2012). The model F-Score is the sum of two variables: accrual quality and financial performance (Skousen \& Twedt, 2009), can be illustrated in the following equation:

$$
\text { F-Score }=\text { Accrual Quality }+ \text { Financial Performance }
$$

Variable components in the F-Score include two things that can be seen in financial statements, namely accrual quality and Financial Performance. Accrual quality is proxy by accrual RSST that is:

$$
\text { RSST accrual }=\frac{\left(\bigwedge_{\text {WC }+} \bigwedge_{\text {NCO+ }} \bigwedge_{\text {FIN })}\right.}{\text { Average Total Assets }}
$$

Explanation:

WC $($ Working Capital $)=($ Current Assets - Current Liability $)$

NCO $($ Non-Current Operating Accrual $)=($ Total Assets - Current Assets - Invesment and Advances $)-$ (Total Liabilities-Current Liabilities - Long Term Debt)

FIN $($ Financial Accrual $)=$ Total Investment - Total Liabilities

ATS $($ Average Total Assets $)=($ Beginning Total Assets + End Total Assets $): 2$

Financial performance of a financial report can be seen as predicting the occurrence of financial reporting fraud (Skousen \& Twedt, 2009). Financial performance is proxy by changes in accounts receivable, changes in inventory accounts, changes in cash sales accounts, changes to EBIT, namely: 
Financial performance $=$ change in receivable + change in inventories + change in cash sales + change in earnings

Explanation:

Change in receivables $=\frac{\Delta \text { Receivables }}{\text { Average Total Assets }}$

Change in inventories $=\frac{\triangle_{\text {Inventories }}}{\text { Average Total Assets }}$

Change in cash sales $=\frac{\bigsqcup_{\text {Sales }}}{\text { Sales }(t)}-\frac{\bigsqcup_{\text {Receivables }}}{\text { Receivables }(t)}$

Change in earning $=\underline{\text { Earnings }(t)} \quad-\quad \underline{\operatorname{Earning} s(t-1)}$

Average Total Assets ( $t$ Average Total Assets $(t-1)$

The population in this study is manufacturing companies that have been listed on the Indonesia Stock Exchange in 2015-2017. Sampling was done by purposive sampling in this study. The purposive sampling technique is a technique which takes data with some considerations or criteria. The sample in this study is all Indonesia Stock Exchange-listed manufacturing companies which meet the following criteria:

1. Production companies listed on the Indonesia Stock Exchange for the period 2015-2017.

2. Companies which experience profits during the observation period and use the rupiah as the currency of reporting.

The regression model used is a multiple linear regression model that is preceded by testing classical assumptions. The relationship between financial report fraud and pressure is presented with a regression model:

$F-S C O R E=\beta 0+\beta 1 A C H A N G E+\beta 2 R O A+\beta 3 L E V+e$

\section{Data Analysis And Discussion}

The results of determining the sample based on purposive sampling criteria obtained 207 observation periods consisting of 69 companies. Of the 158 manufacturing companies listed on the Indonesia Stock Exchange, 47 have suffered losses, and 32 have used currencies other than the rupiah. Classical assumption testing shows the regression model has normal distribution; no autocorrelation, no multicollinearity, and homoscedasticity (Appendix 1). The regression model in the initial test encountered a normality problem, so it needs to be improved by doing an outlier on 12 observations with a Z-Score above 3.00. The final data used is 195 observations.

Score $>$ 3.00. The final data used consists of 195 observations. The testing of the hypothesis shows that financial stability and external pressure have a positive effect on fraud in financial reports. Financial stability is one form of pressure which could encourage fraud in financial statements. SAS No. 99 states that managers tend to commit fraud in financial statements when financial stability and/or profitability are threatened by economic circumstances, industry or the operating entity's situation (Skousen et al., 2009). Companies with growth below the average in the industry tend to manipulate financial statements to improve business prospects (Skousen et al., 2009). These results support the hypothesis proposed, namely financial stability has a positive effect on fraud in financial reporting.

External Pressure is excessive Management Pressure to meet third party requirements or expectations. The need for external financing relates to cash generated from operational and investment activities (Skousen et al., 2009). Companies that use their own funds tend to have a higher chance of profit than using external funds. Research conducted by (Skousen et al., 2009) proves that the higher the free cash flow ratio, the lower the company's likelihood of committing fraud. Based on the results of the testing of the hypothesis, external pressure was found to have a negative impact on fraud in financial statements. This is based on the results of statistical tests that show a significance value (level of 
significance) of 0,000 or less than 0.05 . This result is in line with the research of (Sihombing \& Rahardjo, 2014) and (Maghfiroh, 2015).

Financial objectives are excessive management pressure to achieve the financial targets set by directors or shareholders. The target set encourages management to manipulate profits to meet the benchmarks of analysts, such as the profit from the previous year. The test results show that financial goals have no effect on financial statement fraud. These results can be seen at a significance value of 0.126>0.05. This result is consistent with the research conducted by (Skousen et al., 2009), (Sihombing \& Rahardjo, 2014) who said that financial target variables proxy by ROA did not affect financial statements of fraud. (Aprillia et al., 2015) and (Sari, 2016) it was also found that the financial targets did not affect the fraud in the financial statements.

\section{Conclusions, Limitation, and Suggestion}

Based on the results of the analysis and discussion of the data, it can be concluded that financial stability and external pressure have a positive effect on financial report fraud.This research focuses only on aspects of pressure as part of triangle fraud so that only 16.8 percent when viewed from the adjusted R-Square value while the rest are influenced by other factors. Future research can deeper identify other factors that may be influencing fraud in financial statements. The next researcher is wished to find other proxy variables suspected having effect on fraudulent financial reporting.

\section{References}

[1]Annisya, M., \& Asmaranti, Y. (2016). Matriks jurnal 9. The detection of fraudulent financial statement using diamond fraud . Jurnal Bisnis Dan Ekonomi, 23(1), 72-89.

[2]Aprillia, A., Cicilia, O., \& Pertiwi Sergius, R. (2015). The effectiveness of fraud triangle on detecting fraudulent financial statement: using beneish model and the case of special companies. Jurnal Riset Akuntansi Dan Keuangan, 3(3), 786. https://doi.org/10.17509/jrak.v3i3.6621

[3]Clinard, M. B., \& Cressey, D. R. (1954). Other People's Money: A study in the social psychology of embezzlement. American Sociological Review, 19(3), 362. https://doi.org/10.2307/2087778

[4]Dalnial, H., Kamaluddin, A., Sanusi, Z. M., \& Khairuddin, K. S. (2014). Detecting fraudulent financial reporting through financial statement analysis. Journal of Advanced Management Science, 2(1), 17-22. https://doi.org/10.12720/joams.2.1.17-22

[5]Dechow, P. M., Hutton, A. P., Kim, J. H., \& Sloan, R. G. (2012). Detecting earnings management: a new approach. Journal of Accounting Research, 50(2), 275-334. https://doi.org/10.1111/j.1475679X.2012.00449.x

[6]Jensen, M. C., \& Meckling, W. H. (1976). Theory of firm: managerial behaviour, agency cost, and ownership structure. Journal of Financial Economics, 3, 305-360.

[7]Kasmir. (2019).Financial Statement Analysis. Jakarta Rajawali Persada. Journal of Business \& Banking, 6(2). https://doi.org/10.14414/jbb.v6i2.1299

[8]Maghfiroh, N. (2015). Analysis of the influence of financial stability, personal financial need, external pressure, and ineffective monitoring in financial statement fraud in Fraud perspective. Jurnal Ekonomi Dan Bisnis, 16(1), 51-66.

[9]Murtanto, \& Umar, H. (2016). Analysis of financial statements fraud through fraud diamond factors. APMAA 12th Annual Conference A 2016.

[10]Nursani, R., \& Irianto, G. (2016). Student academic cheating behavior: Dimension of fraud diamond. Jurnal Ilmiah Mahasiswa FEB, 2(2), 15.

[11]Putri, I. G. A. E. P., Sulindawati, N. L. G. E., \& Atmadja, A. T. (2017).The influence of financial targets and ineffective monitoring to cheating (Case study in Koperasi Serba Usaha Dana Pertiwi Seririt, Districts Seririt, Buleleng, Province Bali). E-Journal Akuntansi Ganesha, 7(1).

[12]Quraini, F., \& Rimawati, Y. (2019). Determinan fraudulent financial reporting using fraud pentagon analysis. Journal of Auditing, Finance, and Forensic Accounting, 6(2), 105. https://doi.org/10.21107/jaffa.v6i2.4938

[13]Sari, S. T. (2016). The influence of financial stability, external pressure, financial targets, ineffective monitoring, rationalization in financial statement fraud with fraud triangle perspective. Jurnal Online Mahasiswa Fekon, 3, 664. 
[14]Sihombing, K. S., \& Rahardjo, S. N. (2014). The influence of fraud diamond in financial statement fraud detection (Empirical study in retail company listed on Indonesian Stock Exchange year 2014 2016). Diponegoro Journal of Accounting, 3, 1-12.

[15]Skousen, C. J., Smith, K. R., \& Wright, C. J. (2009). Detecting and predicting financial statement fraud: The effectiveness of the fraud triangle and SAS No. 99. Advances in Financial Economics, 13, 5381. https://doi.org/10.1108/S1569-3732(2009)0000013005

[16]Skousen, C. J., \& Twedt, B. J. (2009). Fraud score analysis in emerging markets. Cross Cultural Management: An International Journal, 16(3), 301-316. https://doi.org/10.1108/13527600910977373

[17]Wolfe, D. T., \& Hermanson, D. R. (2004). The fraud diamond: considering the four elements of fraud: certified public accountant. The CPA Journal, 74(12), 38-42. https://doi.org/DOI 